\title{
室内空気中フタル酸エステル類の捕集方法の検討
}

\author{
メリキザットアブラト ${ }^{1)}$ ，堀 雅宏 ${ }^{2}$ \\ 1)東京工業大学大学院 情報理工学研究科 ₹152-8550 東京都目黒区大岡山2-12-1 \\ 2)横浜国立大学 教育人間科学部 干240-8501 神奈川県横浜市保土ヶ谷区常盤台79-2
}

\section{Studies on the sampling method of phthalic acid esters in indoor air}

\author{
Melikizat $\mathrm{ABLAT}^{1)}$ and Masahiro $\mathrm{HORI}^{2)}$ \\ ${ }^{1)}$ Graduate School of Information Science and Engineering, Tokyo Institute of Technology \\ 2-12-1, Ookayama, Meguro-ku, Tokyo, 152-8550, Japan \\ ${ }^{2)}$ Faculty of Education and Human Sciences, Yokohama National University \\ 79-2, Tokiwadai, Hodogaya-ku, Yokohama, 240-8501, Japan
}

\section{要 旨}

プラスチックの可塑剤として使われている準揮発性有機化合物 (SVOC)であるフタル酸ジ- $n$-ブチル (DBP), フタル酸ジ-2-エチルヘキシル(DEHP) およびフタル酸ジェチル(DEP)について室内環境中での存在形態を知 るための捕集方法を検討し，ガラス繊維フィルター1枚と $\mathrm{C}_{18}$ 多孔性フッ素樹脂フィルター2枚を用い，壁紙

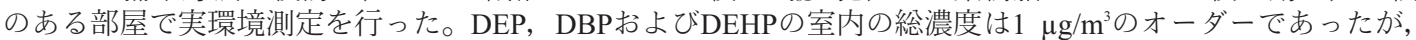
分子量の小さいDEPは99\%以上がガス態，分子量の大きいDEHPは $60 \%$ 以上が粒子態として捕集され，中間 のDBPは大部分ガス態であったが，低室温では粒子態の存在割合が増加する傾向が見られた。また，拡散膜 を使用せず風防を持つ拡散取り込み速度の大きい自製のSVOC用パッシブサンプラーについてアクティブサ ンプラーと並行測定を行い，DEP，DBP㧍よびDEHPの拡散取り込み速度を求めた。さらに拡散係数推算式 から求めた拡散係数を用いて算出した理論拡散取り込み速度と比較した。その結果，ガス態のDEPとDBPは ほぼ一致したが，別の測定で気流の拡散取り込み速度への影響屯確認されたので，適用性についてはさらに 検討する必要がある。

\begin{abstract}
Phthalic acid esters (PAE) are typical substances of semi-volatile organic compounds (SVOC) and are widely used as plasticizers. This study performed fundamental examination on gas-particulate phase percentage in indoor air of three PAEs, namely DBP, DEP and DEHP by employing a glass fiber filter and two $\mathrm{C}_{18}$ porous polyflon filters in a room that wallpaper was used. The mean concentrations of PAE were the order of $1 \mu \mathrm{g} / \mathrm{m}^{3}$. DEP of small molecular weight was almost gas-phase and more than $60 \%$ of DEHP of large molecular weight was particle-phase. On the other hand the greater part of DBP of middle molecular weight was gas-phase, however, when the room temperature was low, the percentage of particulate phase tended to increase.

Authors have made a passive sampler for SVOC, which is large in a sampling rate due to a windbreaker and diffusion-membrane-less sampling face. Parallel measurement with both active and passive sampling was applied to obtain the sampling rates of DEP, DBP and DEHP. In addition, the measured sampling rate was compared with theoretical sampling rate, which was calculated with a sampler dimension and diffusion coefficients. The sampling rates of gas-phase DEP and DBP were almost consistent with the theoretical sampling rates. However, further investigations should be required on the practical application of this passive sampler, because the influence of airflow was significantly found on the sampling rates.
\end{abstract}

Key words: SVOC (Semi-Volatile Organic Compounds)，フタル酸エステル (PAE) (Phthalic Acid Esters)，ガス態(Gas Phase)，粒子態(Particle Phase)，パッシブサンプラー (Passive Sampler)，拡散取り込み速度(Sampling Rate)

\section{1.はじめに}

近年建材・家具・家電製品などに用いられている プラスチックに可塑剤として含まれている準揮発性

受付：2010年10月15日(Received：15 October 2010)

受理：2011年3月22日(Accepted：22 March 2011)
有機化合物 (SVOC：Semi-Volatile Organic Compounds）の代表的な物質として知られているフタル 酸エステル類(以下PAE) はプラスチックに柔軟性を 与え, 加工をしやすくするために添加する物質であ $り^{1)}$, その他に化粧品・香水, インク, 接着剂, 塗 
料等の保留剤としても広く利用されている ${ }^{2-4}$ が，生 殖障害を起こす原因となる内分泌擋乱物質の観点な どから污染物質として注目されている, 境空気中にガス態として揮散されるが, 蒸気圧が低 いために吸着されやすく, ガス・粒子分配が問題に なる。これらを扱った研究はあまり多くはないが, PAEの正確な定量が困難であることもその理由のひ とつと考えられる》。また, 室内環境であPAEの存 在形態に関しての情報は少ない。PAEの室内空気中 での滞留時間, 化学変化や蓄積を明らかにするため にはPAEの室内環境中での捕集方法を改良すること は対策や存在形態の検討と合わせて重要である。現 在SVOCの濃度評価のために用いられているサンプ リング法はアクティブサンプリングで, ポンプ設置 場所, 騒音, 操作性など実態調査に不向きな点が多 いが，パッシブサンプリングについては，SVOCの 適応事例がほとんどない。

このような背景のもと, 本研究では室内環境中 SVOCの捕集方法について基礎的な検討を行うとと あに，ガス・粒子態の存在割合について考察した。 また, 従来VOCや反応性の無機ガスの捕集に使わ れてきたパッシブサンプラーをSVOCに適用するこ とを検討した。

ここではPAEとして蒸気圧が異なり, よく利用さ れている3種のフタル酸ジ- $n$-エチル(DEP), フタル 酸ジ-n-ブチル (DBP), フタル酸ジ-2-エチルヘキシ ル(DEHP)を取り上げた。

\section{2. 実験方法}

\section{1 フィルター捕集方法}

アクティブサンプリングのフィルター捕集装置を Fig.1に示す。ガラス繊維フィルター1枚(以下 GF, 直径47 mm, GB-100R, ADVANTEC社製) とエムポ アディスク $\left(\mathrm{C}_{18}\right.$ 多孔性フッ素樹脂フィルター, 直径 $47 \mathrm{~mm}, 3 \mathrm{M}$ 社製) 複数枚を重悋てホルダー(EMO47, GLサイエンス社製)にセットし, ダイアフラム ポンプ(柴田科学工業社製)に接続した。捕集装置を 三脚架台に取り付け, 対象住宅Aの床上 $1.2 \mathrm{~m}$ にお いて, 流量 $9.1 \mathrm{~L} / \mathrm{min} て ゙ 24$ 時間室内空気を採取し, それを分析用試料とした。採取後, 分析試料をアル ミ袋に密封し, 前処理直前まで冷蔵庫で保管した。

ここで, 前段の GFで粒子態のPAE, 後段のエム ポアディスクでGFを通過したガス態のPAEが捕集 されると推定した。さらに，GFに保持された粒子
態のPAEが通気時間の経過とともに揮発する量を測 定するために, 対象住宅Bにおいて, 対象住宅A 同様な測定条件で24時間サンプリングしたGFを前 段に, 洗浄済みの未使用のエムポアディスクを後段 にセットし, HEPAフィルターと活性炭カートリッ ジを通した清浄空気を3，9，24時間通気後，エンポ アディスク上のPAEを定量した。

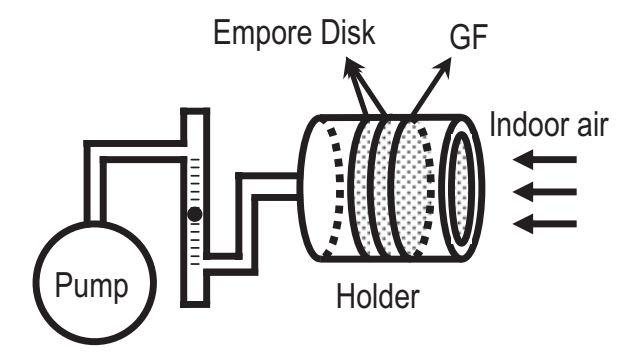

Fig.1 Proposed sampling method of PAE for the gasparticulate phase partitioning by employing glass fiber and Empore disk filters

\section{2 SVOCパッシブサンプラーの検討}

\section{2.1 実験概要}

パッシブサンプラーは分子拡散現象を利用して空 気質を捕集する。そのため, アクティブサンプラー に扮けるポンプの吸引速度に相当するものは拡散取 り込み速度(捕集速度)あるいはサンプリングレート (SR) と呼ばれている。

本研究では, SVOCパッシブサンプラーの拡散面 積・拡散距離と拡散係数推算式による求めたDEP, DBP, DEHPの分子拡散係数を用い, 拡散理論式に よるDEP, DBP, DEHPの拡散取り込み速度を算出 する。さらに，アクティブサンプリングとパッシブ サンプリングで並行測定を行い, 実験からDEP, DBP, DEHPの拡散取り込み速度を求める。そして, 理論と実験による拡散取り込み速度を比較し, この SVOCパッシブサンプラーの適用性の検討を行う。

本研究で提案するSVOCパッシブサンプラーは, 従来同じ目的に使われるVOC捕集用パッシブサン プラーなどに比べて構造上の工夫点がある。それは, 捕集対象物質の吸着や拡散抵抗となる拡散膜を使用 せず，拡散面積を広くとりかつ両面から捕集できる 構造にしたこと，さらに吸着面に気流が直接当たる のを避けるため吸着面の周辺を囲む風防 (ホルダー) を長めにとったことである。サンプラーの構造を Fig.2に示す。捕集剤のエムポアディスク1枚を2枚 
金網 (60メッシュ, 直径 $46 \mathrm{~mm}$ )の中に挟み, 円筒 形のアルミホルダー(長さ $50 \mathrm{~mm}$, 内径 $46 \mathrm{~mm}$, 外 径50 $\mathrm{mm}$ )の中心部に固定させた。それを対象住宅 $\mathrm{A}$ の床上 $1.2 \mathrm{~m}$ の高さで, 水平に(サンプリング面が 横向き)吊るし，72時間放置し，試料を採取した。 採取後の保存方法は2.1と同じである。

さらに，気流の拡散取り込み速度への影響を見る ためにはアクティブサンプラーとの並行測定におい て3個のSVOCパッシブサンプラーを用いた。1個は 部屋の中央部に，他の二つはサンプリング面を互い に90度になるように設置し，それらのパッシブサン プラー表面近傍には小型ファンで $0.2 \mathrm{~m} / \mathrm{s}$ の気流を 当てた。気流の大きさは風速計で測定し, 小型ファ ンの電源電圧を変えて制御した。これらの位置関係 はFig.3に示す。

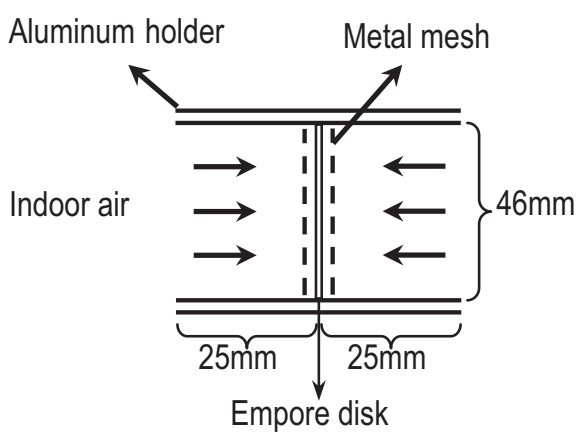

Fig.2 Structure of SVOC passive sampler

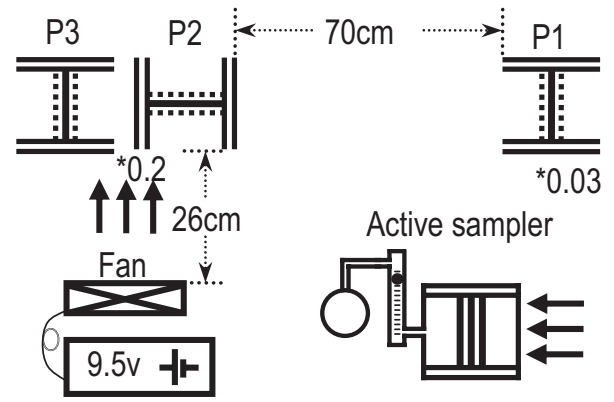

Fig.3 Positions of SVOC passive sampler, active sampling device and fan in the measurement room

\section{2.2 拡散取り込み速度の算出法}

(1) 実験による拡散取り込み速度の算出法

PAEの中でDEP, DBP, DEHPの拡散取り込み速 度を式 $(1)^{8)}$ によって求めた。拡散取り込み速度と 濃度, サンプルの捕集量の関係は式(1)で示されて いる。

$$
S R=\frac{W}{C \times t}
$$

ここで, $S R$ は拡散取り込み速度 $(\mathrm{ml} / \mathrm{min}), t$ は暴 露時間 $(\min ), C$ と $W$ はそれぞれ並行測定により求 めた室内の濃度 $(\mathrm{ng} / \mathrm{L})$, パッシブサンプラーの捕集 量(ng)である。

(2) 拡散理論式による拡散取り込み速度の算出法 本研究で提案するSVOCパッシブサンプラーの理 論拡散取り込み速度を算出するために, DEP, DBP, DEHPの分子拡散係数 $\left(\mathrm{cm}^{2} / \mathrm{s}\right)$ は拡散係数推算式 (2) から概略值を求めた。また, 文献值とも比較した。

$$
\frac{D}{D_{\text {ref }}} \approx\left[\frac{M}{M_{\text {ref }}}\right]^{-1 / 2}
$$

ここで, $D$ と $M$ は未知対象物質の気相中の分子拡 散係数 $\left(\mathrm{cm}^{2} / \mathrm{s}\right)$ 之分子量, $D_{r e f}$ 之 $M_{r e f}$ は既知参考物質の 気相中の分子拡散係数係数 $\left(\mathrm{cm}^{2} / \mathrm{s}\right)$ と分子量である。 そこでこの実験で用いたSVOCパッシブサンプ ラーの拡散面積, 拡散距離と式(2)で算出した分子 拡散係数の推算值を用い, 式 $(3)^{8)}$ に代入し, 拡散 理論による, DEP, DBP, DEHPの理論拡散取り込 み速度を求めた。

$$
S R=\frac{60 \times A \times D}{Z}
$$

ここで, $S R$ は拡散取り込み速度 $(\mathrm{ml} / \mathrm{min}), Z$ は拡 散距離 $(\mathrm{cm}), A$ は有効拡散面積 $\left(\mathrm{cm}^{2}\right), D$ は空気中 に掞ける物質の分子拡散係数 $\left(\mathrm{cm}^{2} / \mathrm{s}\right)$ である。

\section{3 使用機器と分析条件}

PAEの分析には, ガスクロマトグラフー質量分析 計GC-MS (353, GLサイエンス社製)を使用し, 分離 カラムには $(\mathrm{Cp} 1301,30 \mathrm{~m} \times 0.25 \mu \mathrm{m} \times 1 \mu \mathrm{m})$ を用 いた。カラムの昇温条件は, $100^{\circ} \mathrm{C}$ で 2 分保持後 $10^{\circ} \mathrm{C}$ $/ \min$ で $190^{\circ} \mathrm{C}, 1^{\circ} \mathrm{C} / \min$ で $210^{\circ} \mathrm{C}, 5^{\circ} \mathrm{C} / \mathrm{min}$ で $260^{\circ} \mathrm{C}$ ま で昇温させ 17 分間保持した。キャリアガスは $\mathrm{He}$

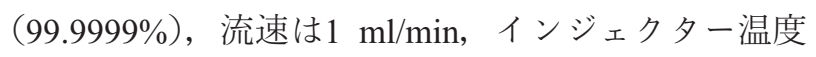
は $280^{\circ} \mathrm{C}$ である。測定モードはSCAN $(m / z=40 \sim 350)$ である。標準物質のマススペクトルと試料のマスス ペクトル及び保持時間を比較することにより同定し た。 
サンプリングの時の室内温湿度は, 温湿度連続測 定器(TR-72Sティ・アンド・ディ社製)により1時間 間隔で自動測定し，サンプリング時間数の平均值を 算出した。

\section{4 抽出操作}

試料の抽出は以下のように行った。フィルター捕 集方法では採取したGFとエムポアディスクをホル ダーから取り出し, それぞれを $10 \mathrm{ml}$ の栓付き試験 管に移し，アセトンを10 ml加え，20分超音波で抽 出を行った（GFとエムポアディスクをサンプリング 前の洗浄操作も同様である)。他の操作は以下の通 りである。抽出液を遠心分離行った後, 高純度窒素 ガスで吹き付けながら $0.5 \mathrm{ml}$ まて濃縮した。そのう ちの2 $4 \mathrm{l}$ をGC-MSに導入し, 定量分析を行った。

\section{5 試薬(略号)}

PAEの標準品：フタル酸ジェチル (DEP), フタル 酸ジ-n-ブチル (DBP), フタル酸ジ-2-エチルヘキシ ル (DEHP) (以上, フタル酸エステル, GLサイエン ス社製)

その他の試薬：環境分析用アセトン(試料抽出の 時, 和光純薬工業社製), 残留農薬試験用アセトン (フィルターの洗浄の時, 和光純薬工業社製), メ夕 ノール (残留農薬試験用, 和光純薬工業社製)。高純 度窒素ガス, 固相ディスク(住友スリーエム社製) エ ムポアディスク $\mathrm{C}_{18}$ を用いた。

\section{6 対象住宅}

神奈川県内の居住住宅において室内空気中におけ るPAEの濃度測定を行った。対象住宅Aは木造, 築 年数 29 年のアパート住宅であり, 測定した部屋の大 きさは6畳の寝室である。測定は2007年2月～11月に かけて5回行った。サンプリング時は換気設備をオ フにし, 自然換気のみの条件とした。一方, GFの 保持特性と気流の拡散取り込み速度への影響は対象 住宅Bにおいて測定を行った。それは鉄筋コンクリー トの集合住宅であり，測定した部屋の大きさは6畳 のリビングで, リフォームから 1 年 6 月月後に測定し た。

\section{7 ガス・粒子態の存在割合の計算方法}

室内環境中SVOCのガス・粒子態の存在割合につ いて検討を行った。粒子態の存在割合 $R_{P}(\%)$, ガス
態の存在割合 $R_{g}(\%)$ は式(4)，（5）により算出した。

$$
\begin{aligned}
& R_{P}(\%)=\frac{W_{P}}{W_{\text {total }}} \times 100 \% \\
& \boldsymbol{R}_{g}(\%)=\frac{W_{g}}{W_{\text {total }}} \times 100 \%
\end{aligned}
$$

ここで， $W_{p}$ はGFで捕集されたPAEの捕集量 $(\mathrm{ng})$, $W_{g}$ はエムポアディスクで捕集されたPAEの捕集量 $(\mathrm{ng}), W_{\text {total }}$ は $W_{p}$ と $W_{g}$ の合計值 $(\mathrm{ng})$ である。

\section{3. 結果および考察}

\section{1 フィルター捕集方法}

\subsection{1 フィルターブランクの検討}

市販のエムポアディスクを 2.4 に述べた抽出操作 に従って洗浄し，その操作を5回繰り返し行なった。 1，3，5回目に検出された重量をTable 1に示した。 この結果，4回以上洗浄すればPAEの污染物質はほ ぼ除去できることが確認された。一方，無機繊維の GFは1回目の洗浄值もTable 1に合わせて示したが, 1 回洗浄でのブランク值は今回の試料レベルの $1 / 10$ 倍以下になり十分無視できる量であった。

この結果を踏まえて, エムポアディスクと GFは 種々の物質で高濃度に污染されているため, そのま ま使用することがなく，エムポアディスクは5回， GFは1回洗浄し，PAEのサンプリングに使用した。 また, 環境污染からなるべく防ぐために, この洗浄 操作をいつもサンプリングの直前に行った。分析に 使用するホルダー, ガラス器具などをアセトンで十 分に洗浄した。

試料の保存や運搬による污染を調べるために, 卜 ラベルブランク試験を行った。洗浄済みのフィルター をFig.1のようにセットし，アルミ容器に入れて密 封し, サンプリング場所まで移動した。それを試料 と同様に前処理し, 分析を行い, トラベルブランク 值を求めた。それを試料の定量值から差引いた。

\section{1.2 フィルターの捕集特性}

(1) エムポアディスクの捕集特性

エムポアディスクの捕集特性を検討するために, 対象住宅Aにおいて, GF1枚とエムポアディスク3枚 で構成されたフィルター捕集方法を用い，2.1.1の同 様にサンプリングし, 分析した。室内の環境条件は (湿度 : $67 \%$, 室温 : $15^{\circ} \mathrm{C}$, 換気回数 : 0.6 回 $/ \mathrm{h}$ )であ る。結果はFig.4に物質種類別の捕集された絶対量 


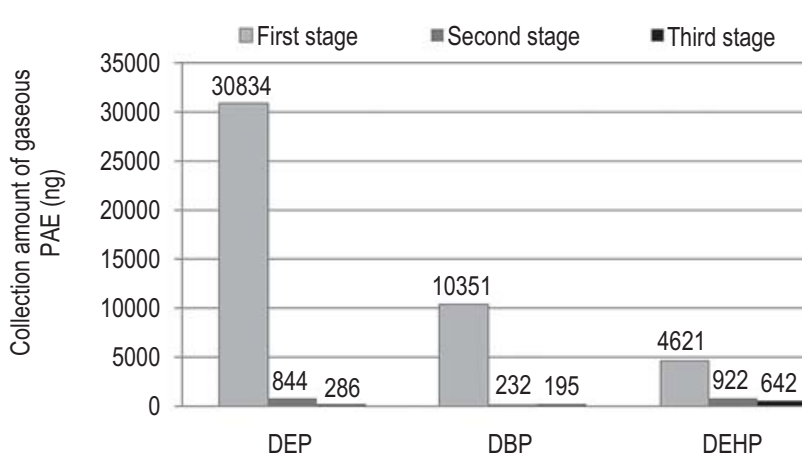

Fig.4 Collection amount of gaseous PAE on the serially jointed Empore disks

として示した。

エムポアディスク3枚で捕集された全捕集量を 100 \%とすると，エムポアディスクの1段目と2段目で捕 集されたDEPとDBPの捕集量が全捕集量の $99 \%$, DEHPが $90 \%$ という高い捕集率を示した。そこで, この結果を踏まえて, これからの室内空気中のPAE の捕集にはエムポアディスク2枚を用いることにし た。ただし，DEHPの捕集率の正確度は，DEHPの 捕集量がDEPやDBPより少ない上に，それらよりも 分析時の污染の影響屯受けやすいために低いと考え られる。PAEの中で特にDEHPについてはトラベル

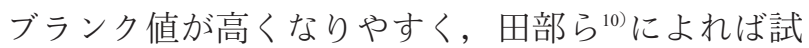
料を採取し，実際分析するまでの間の污染の検討実 験では試料の保存期間 5 日目では1日目と比較して DBPは約3倍，DEHPは約6倍のブランクが検出され， 試料を採取後早く分析を行う必要があることが認め られている。そこで, 筆者らはそれに従い, 試料の 保存期間を 24 時間以内で分析した。なお，高橋ら ${ }^{11}$ あPAEの分析ではガラス器具やGC-MS装置用の注 入口セプタム, ガス管, カラムインサートからの污 染を指摘している。

(2) GFに捕集されたPAEの保持特性

室内で24時間通気してPAEを捕集したGFに清浄 空気を通気させ，後段のエムポアディスクを定量分 析した結果，エムポアディスクで検出されたDEP,

DBP，DEHPの量は検出下限值以下であった。なお， 清浄空気通気後にGFに保持された粒子態PAEを定 量したところ，捕集量はそれぞれDEP：300 ng, DBP : 840 ng, DEHP : 3330 ngであった。このこ とはGF上のPAEの再揮発は無視できるほど小さい ことを意味する。また, DEP, DBP, DEHP がGF に安定に保持されていることから, エムポアディス クで捕集されたPAEは全てガス態であると考えられ
た。

\section{1. 3 PAEの種類別実測濃度}

対象住宅AにおいてDEP, DBP, DEHPが多く検 出された。なお, 日本はDEPを700トン未満, DBP

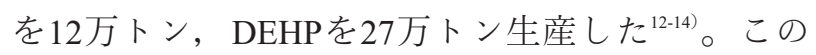
ことからも推測されるが，この測定結果でもPAEの 中でDEP, DBP, DEHPがよく使われていることが 改めて分かった。これ以外のPAEは定量下限值以下 であった。結果はTable 2に示した。これは5回測定 結果の平均值を取った結果である。今回の測定結果 ではDBPとDEHPの濃度はトータル濃度の $56 \%$ を占 めた。この3種類のPAE平均濃度の範囲は $1 \mu \mathrm{g} / \mathrm{m}^{3}$ 前 後であった(順に1.04, $\left.0.78,0.52 \mu \mathrm{g} / \mathrm{m}^{3}\right)$ 。 Table 2 に示すように濃度は蒸気圧 $\left(\mathrm{DEP}: 9 \times 10^{-2} \mathrm{~Pa}, \mathrm{DBP}\right.$ : $1.5 \times 10^{-3} \mathrm{~Pa}$, DEHP : $\left.1.9 \times 10^{-5} \mathrm{~Pa}\right)^{15)}$ の高い順位に なった。

今回の濃度レベルは厚生労働省の指針值 (DBP： $220 \mu \mathrm{g} / \mathrm{m}^{3}$, DEHP : $\left.120 \mu \mathrm{g} / \mathrm{m}^{3}\right)^{16)}$ の約 $1 / 100 \sim 1 / 200$ であり, かなり低いことが分かった。DEHPより使 用頻度が少ないDEPの濃度平均值はDEHPとDBPよ り高く検出された。一方, 筆者らが築年数 5 年の一 戸建て住宅において，壁紙とフロリングで内装され た床面積 $16 \mathrm{~m}^{2}$ の非居住寝室で2007年10月と12月に 測定した結果, 室内空気中DEP, DBP, DEHPの濃 度はそれぞれ0.1， $0.25 ， 0.7 \mu \mathrm{g} / \mathrm{m}^{3}$ であった。これ は今回対象にした部屋が化粧品・香水が置いた女性 の寝室であったためと推察される。また, 壁紙の可 塑剂に添加剂として最も多く $(56 \%)$ 用いられている $\mathrm{DEHP}^{9)}$ よりDBPの濃度が高かったのはDBPとDEHP の蒸気圧の差が100倍以上異なるためと考えられ， またDEPやDBPは添加剤以外に相溶剤や保留剂に使 われているので，その製品群もPAEの濃度に大きく 寄与していると考えられる。なお，これらに関して は斎藤ら ${ }^{17)}$ 屯同様な考察を行っている。

Table 1 Effect of washing on the clearance of PAE in the blank filters

\begin{tabular}{l|r|r|c}
\hline \hline & DEP & DBP & DEHP \\
\hline First washing of Empore & 946 & 60 & 44 \\
\hline Third washing of Empore & 18 & 7 & 29 \\
\hline Fifth washing of Empore & N.D. & N.D. & N.D. \\
\hline First washing of GF & N.D. & 8 & 10 \\
\hline
\end{tabular}

Unit: ng, N.D.: Not detected 
Table 2 Indoor air concentrations of gaseous, particulate and total PAE measured at the residence in Kanagawa, Japan

\begin{tabular}{|c|c|c|c|}
\hline Analyte & Gas-phase & Particle-phase & Total \\
\hline DEP & $1.04(0.50-2.36)$ & $0.002>$ & 1.04 \\
\hline DBP & $0.75(0.10-1.53)$ & $0.03(0.01-0.05)$ & 0.78 \\
\hline DEHP & $0.29(0.07-0.59)$ & $0.23(0.09-0.39)$ & 0.52 \\
\hline
\end{tabular}

Unit: $\mu \mathrm{g} / \mathrm{m}^{3}$, Mean (Minimum, Maximum), $(n=5)$

Detection limit: DEP: $2 \mathrm{ng} / \mathrm{m}^{3}$, DBP: $1 \mathrm{ng} / \mathrm{m}^{3}$, DEHP: 1.5 $\mathrm{ng} / \mathrm{m}^{3}$

\section{1.4 ガス・粒子態の存在割合と室温の影響}

PAE存在形態の研究はPAEの室内環境污染で重要 な意味を持っている。対象住宅Aの測定值を用いて, 粒子・ガス態合計值に占めるガス・粒子態物質の割 合について解析を行った結果はFig.5に示す。

Fig.5には室温条件とガス態の割合の関係を示し た。室温 $12^{\circ} \mathrm{C} \sim 34^{\circ} \mathrm{C}$ 範囲において, 沸点 $298^{\circ} \mathrm{C}$, 分子量 (222) が小さいDEPが室温の変化にかかわら ず，すでに $99 \%$ 以上がガス態として捕集された。沸 点 $340^{\circ} \mathrm{C}$, 分子量 (278)のDBPはガス態として捕集さ れる割合 $(63 \%$ \% $6 \%$ ) は高いが，低温では粒子態の 割合が増加する傾向が見られ，最大で $37 \%$ 粒子態之 して捕集された。沸点 $390^{\circ} \mathrm{C}$ ，分子量(390)が大きい DEHPの粒子態の割合 $(51 \% \sim 84 \%)$ は高いが，室温 $28^{\circ} \mathrm{C}$ 以上ではガス態としての割合が増加し，60\%以 上がガス態として捕集されていた。

この結果からはフタル酸エステルの存在形態と分 子量の間では高い依存性があることが考えられる。 また，室温とガス・粒子態の存在割合の間に相関関 係が見られた。なお，Wang ら の研究では分子量 $<$ 252(フタル酸ジメチルとフタル酸ジェチル)がほと んよ゙ガス態であり, 分子量 $>252$ は粒子態の可能性 が大きく，フタル酸エステルのガス・粒子分配は PAHなど他の有機化合物と同様に分子量と高い依存

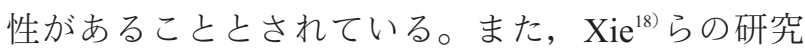

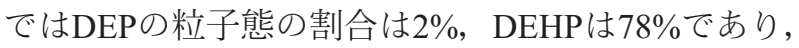
本研究の測定結果の最大值とほぼ一致した。

なお，粒子態のPAEとは，空気中にエアロゾル粒 子として存在するPAEであり，粒子状PAE自体ある いはエアロゾル粒子に吸着した状態のものが想定さ れる。

本研究ではGFで捕集された成分を粒子態として 評価したが，PAEの蒸気圧が低く $\left(10^{-3} \sim 10^{-5} \mathrm{~Pa}\right)^{15)}$, 吸着性が高い物質であるので，ガス態の一部は粒子
態として計測した可能性がある。GF上でのガス吸 着率はさらに検討されなければならないが, DEHP についてはガスが前段で拡散捕集される拡散スクラ

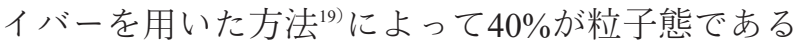
ことが鍵らによって確認されている。

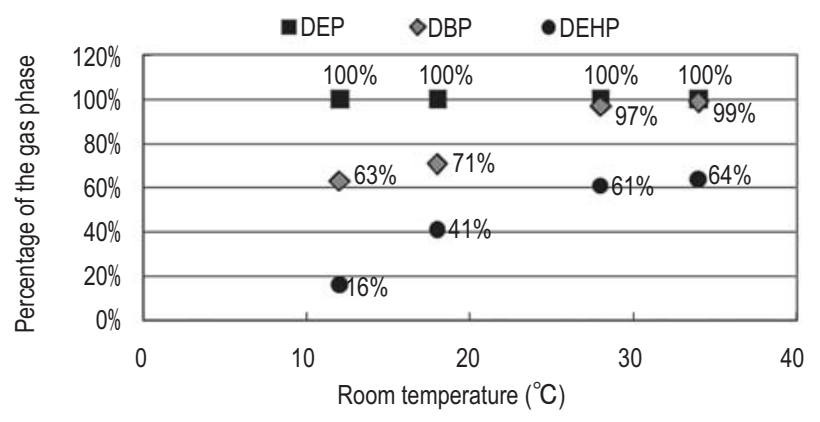

Fig.5 Relationship between room temperature and percentage of phthalates in the gas phase

\section{2 SVOCパッシブサンプラーの検討}

\section{2.1 拡散取り込み速度}

（1）実験による拡散取り込み速度の算出法 パッシブサンプラーの暴露時間，捕集量とアクティ ブサンプリング法で求めたガス濃度からSVOCパッ シブサンプラーの拡散取り込み速度を式(1)より算 出した。このSVOCパッシブサンプラーのDEP及び DBPに対する拡散取り込み速度はそれぞれ34，35 ml/minであった (Table 3)。一方, DEHPは $52 \mathrm{ml} /$ minであり，ばらつきが大きく，DEPとDBPより大 きかった。

(2) 拡散理論式による拡散取り込み速度の算出法 この実験で用いたSVOCパッシブサンプラーの拡 散距離 $(Z)$ は2 $25 \mathrm{~mm}$ であり, 有効拡散面積 $(A)$ は16.6 $\mathrm{cm}^{2}$ である。ここで, 分子拡散係数推算式(2) から求 めたDEP，DBP，DEHPの分子拡散係数は順に0.053， $0.048,0.042 \mathrm{~cm}^{2} / \mathrm{s}$ とった。

そこで，拡散理論式(3)に従ってDEP, DBP, DEHPの理論拡散取り込み速度を求めた。結果は順 にTable 3に示すように $42,38,32 \mathrm{ml} / \mathrm{min}$ になった。 (3) 拡散理論による算出した拡散取り込み速度と 実験による拡散取り込み速度の比較

理論と実験により得られた拡散取り込み速度を比 較した結果，DEPとDBPに対しては，それぞれ $19 \%$, $8 \%$ の違いであった。光崎ら ${ }^{8)}$ は, 実験と拡散理論式 による拡散取り込み速度が等しいならば，拡散理論 に従って算出した拡散取り込み速度は正しいもので 
あると考えた。また，比較する場合は操作・分析䛊 差及び拡散係数の推算値之実測值の差異があるため, 20\%以内であれば一致しているとみなしてよいとし ているが，この判断基準を援用すれば筆者らの場合 あ一致していると言える。その上，3.1.4のフィルター 捕集法によって明らかになったようにDEPとDBPの 存在形態はほとんどガス態であるためにSVOCパッ シブサンプラーが適用できる可能性があると考えら れた。

しかし，DEHPに対しては全く一致しなかった。 DEHPは前述のように分析時の污染の影響も考えら れるが，今回はSVOCパッシブサンプラーで捕集さ れた絶対量が多いので, 寄与率が低いと考えて考察 を試みる。DEHPの分子拡散係数はDEPやDBPより 小さいので, 拡散取り込み速度が大きい結果は逆で 説明がつかない。また, 状態分析の結果約 $50 \%$ が粒 子態であるDEHPは粒子状拡散係数が極端に小さく, 分子拡散係数の $1 / 100$ あるいはそれ以下 ${ }^{19}$ であるの で，見かけ状の拡散取り込み速度は小さくなるはず であるが, 結果は平均 $52 \mathrm{ml} / \mathrm{min}$ で, 逆である。こ れの原因として考えられるのは，このSVOCパッシ ブサンプラーに使用した捕集剤の素材は帯電性の最 大のフッ素樹脂 (PTFE) が使われていて, ガス吸着 の他に微粒子の捕集の可能性がないわけではないの で，仮に，多量の分子が凝縮されている粒子が捕集 されれば，それの影響は大きいと推察される。いず れにしてもDEHPに関してはこのSVOCパッシブサ ンプラーの正確度は低く適用できないと考えられた。

\section{2.2 気流の拡散取り込み速度への影響}

SVOCパッシブサンプラーの適用性の検証を兼称 て時と場所を变え(対象住宅B), 気流の影響を見た。 測定結果をTable 4に示す。测定対象の部屋は空な どを閉鎖した時の気流は $0.03 \mathrm{~m} / \mathrm{s}$ であり, 並行して 測定したアクティブサンプリングによる72時間平均 濃度はDEP : $0.10 \mu \mathrm{g} / \mathrm{m}^{3}$ DBP : $0.17 \mu \mathrm{g} / \mathrm{m}^{3}$, DEHP :
$0.35 \mu \mathrm{g} / \mathrm{m}^{3}$ であった。気流が $0.03 \mathrm{~m} / \mathrm{s}$ のところと 0.2 $\mathrm{m} / \mathrm{s}$ のころの気流に対して捕集量を比較した結果 をTable 4に示した。なお， $0.03 \mathrm{~m} / \mathrm{s}$ はとんど肌 で感じらないが， $0.2 \mathrm{~m} / \mathrm{s}$ は明確に感じられる風速 である。

ここではガス態の DEP, DBPについてみると, P1 とP3の捕集量の差はそれぞれ18\%，11\%であった。 一方, $0.2 \mathrm{~m} / \mathrm{s}$ に打ける気流の向きではP2 と 3 差は 14\%，15\%であった。ここで， 20\%を基準に判断し ても 0.03 と $0.2 \mathrm{~m} / \mathrm{s}$ 及び気流の向きの差は大きいもの とは言えない。一方, この結果をもとに算出した拡 散取り込み速度はDEP：280 $\mathrm{ml} / \mathrm{min}$, DBP : 160 $\mathrm{ml} / \mathrm{min}$ であり, 前節の数值と一致せず, いずれの成 分もかなり高い值になった。このことは風防内で移 流拡散の寄与が大きかったためと推察される。この ことは今回の $0.03 \mathrm{~m} / \mathrm{s}$ と一桁異なる $0.2 \mathrm{~m} / \mathrm{s}$ の間で 20 \%以下の差であった事実と矛盾する。前節の測定は 密閉時の自然換気による気流のみであったのに対し, 今回の $\mathrm{P} 1$ サンプラーはファンから $70 \mathrm{~cm}$ 以上離れ

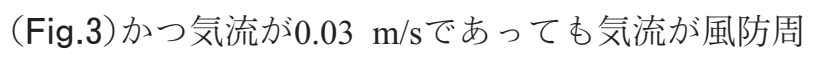
辺および風防内の移流拡散に寄与したためと推測さ れる。このことは気流がある程度あれば，少なくと あ $0.2 \mathrm{~m} / \mathrm{s}$ 以下の範囲では気流の影響を受けないと あいえるが, 室内で受ける実際の気流大きさや気流 の幅と関係を含めて適用性の判断には更なる検討が 必要である。

Table 3 Measured sampling rate and theoretical sampling rate

\begin{tabular}{c|c|c|c}
\hline \hline PAE & DEP & DBP & DEHP \\
\hline Measured sampling rate * & 34 & 35 & 52 \\
& $(30-38)$ & $(32-38)$ & $(34-70)$ \\
\hline Theoretical sampling rate & 42 & 38 & 32 \\
\hline
\end{tabular}

*Mean, $n=2$; Unit: $\mathrm{ml} / \mathrm{min}$

Table 4 Comparison of amount of PAE collected in several wind speed conditions

\begin{tabular}{c|c|c|c|c|c}
\hline \hline \multirow{2}{*}{$\begin{array}{c}\text { Wind speed } \\
(\mathrm{m} / \mathrm{s})\end{array}$} & \multirow{2}{*}{$\begin{array}{c}\text { Angle of sampling } \\
\text { face to wind } \\
\text { direction }\end{array}$} & \multirow{2}{*}{$\begin{array}{c}\text { SVOC } \\
\text { passive } \\
\text { sampler No. }\end{array}$} & \multicolumn{3}{|c}{$\begin{array}{c}\text { Collection amount of } \\
\text { PAE }(\mathrm{ng})\end{array}$} \\
\cline { 4 - 6 } & Parallel & DEP & DBP & DEHP \\
\hline 0.03 & Facing & P2 & 101 & 140 & 708 \\
\hline 0.20 & Parallel & P3 & 115 & 121 & 419 \\
\hline 0.20 & & &
\end{tabular}




\section{4. まとめ}

本研究ではSVOCフィルター捕集法と存在形態に ついて基礎的な検討を行うとともに，SVOCパッシ ブサンプラーへの適用を検討し，以下の結論を得た。

(1) フィルター捕集方法を用いてエムポアディスク の捕集特性を検討した結果, フィルター捕集実 験でGF1枚とエムポアディスク2枚を用いるこ とにした。また，GFの保持特性はよく，GFに 捕集された粒子態のPAEの再揮発は無視できる ことが分かった。

(2) フィルター捕集方法を用い, フタル酸エステル の存在状態について基礎的な検討を行い, フ夕 ル酸エステルの存在形態之分子量の間に高い依 存性があることが確認された。

(3) 壁紙のある部屋で実測し, 存在状態に対する室 温の影響について検討行った結果, 濃度は $1 \mu \mathrm{g} / \mathrm{m}^{3}$ オーダーで厚生労働省の指針值よりか なり低い值であったが, 室温 $12^{\circ} \mathrm{C} \sim 34^{\circ} \mathrm{C}$ 範囲 において, DEPは室温の変化と関係なく, ほぼ ガス態として捕集された。DBPには室温上昇す るとともにガス・粒子態の割合に変化が見られ た。DEHPは低室温では粒子態の割合が増加し, 高室温では低下する傾向が見られた。

(4) 拡散取り込み面に拡散膜を用いない風防だけの SVOCパッシブサンプラーについて, DEP, DBP，DEHPについてそれぞれの実験と拡散理 論式による拡散取り込み速度を求め, 比較した。 その結果, DEPとDBPに関してほぼ一致したが, 気流の影響(移流拡散)による拡散取り込み速度 への影響が認められ, 適用性についてはさらに 検討が必要である。

\section{謝辞}

本研究をまとめるにあたり, 藤井修二教授と諏訪 好英客員教授 (東京工業大学情報理工学研究科) に有 益なご助言をいただきました。ここに記して厚く御 礼を申し上げます。

\section{引用文献}

1) Wensing M., Uhde E. and Salthammer T.: Plastics additives in the indoor environment-flame retardants and plasticizers, Science of the Total Environment, 339, 19-40 (2005).

2）化学工業日報社, 13599の化学商品, 1027(1999).
3) US Department of Health and Human Services, Public Health Service, USA, Toxicological profile for di-n-butyl phthalate, 157 (1993).

4) Canadian Environmental Protection Agency, Canada, Priority Substances List, Environmental Supporting Document, Butyl benzyl phthalate, October (1998).

5）片瀬隆雄：例えば，医学のあゆみ， 83， 17 (1972)/科学, 42, 349(1972).

6) 池本庸, 小寺重行, 桂井清人, 稲葉善雄, 町田 豊平, 田中彰：日本不妊学会雑誌, 28, 159 (1983).

7) Wang P., Wang S. L. and Fan C. Q.: Atmospheric distribution of particulate- and gas-phase phthalic esters (PAEs) in a Metropolitan City, Nanjing, East China, Chemosphere, 72, 1567-1572 (2008).

8）光崎純, 中井里史, 白砂裕一郎, 平野耕一郎: 拡散型サンプラーに抢ける理論的拡散取り込み 速度の算出法の検討, 室内環境学会誌, 9, 115(2006).

9）川本克也, 環境有機化学物質論, 共立出版, 141, p.204-206(2006).

10）田部井昭子, 根津豊彦, 仲山伸次 : 大気中フ夕 ル酸エステル類の分析に関する検討, 日環セ所 報, 28，63-69(2001).

11）高橋哲夫, 平間祐志, 兼俊明夫, 藤本啓, 桂英 二：食品中のフタル酸エステル類の分析につい て, 道衛研所報, 49, 119-122(1999).

12）フタル酸ジェチル，2011年1月14日18:00, http://www.env.go.jp/chemi/report/h16-01/pdf/ chap01/02_2_17.pdf

13）フタル酸ジ-n-ブチル，2011年1月14日18:00, http://www.env.go.jp/chemi/report/h14-05/chap01/ 03/30.pdf

14）フタル酸ジ-2-エチルヘキシル，2011年1月14日 18:00, http://www.env.go.jp/chemi/report/h14-05/ chap01/03/29.pdf

15) Wescher C. J., Salthammer T. and Fromme H.: Partitioning of phthalates among the gas phase, airborne particles and settled dust in indoor environments, Atmospheric Environment, 42, 1449-1460 (2008).

16）厚生労働省，報道発表資料，2002年2月，「シッ クハウス(室内空気污染)問題に関する検討会中 
間報告書一第8回〜第9回のまとめについて」.

17）斎藤育江, 大貫文, 瀬戸博 : 室内空気中フタル 酸エステルの測定，室内環境学会誌，5，13-22 (2002).

18) Xie Z.Y., Ebinghaus R., Temme C., Caba A. and Ruck W.: Atmospheric concentrations and air-sea exchanges of phthalates in North Sea (German
Bight), Atmospheric Environment, 39, 3209-3219 (2005).

19）鍵直樹, 並木則和：室内環境中におけるガスと 粒子のSVOC分離測定の基礎研究, 第27回空気 清浄とコンタミネーションコントロール研究大 会予稿集，129-131(2009). 